\title{
Kinerja Layanan Universitas Islam Indonesia Diukur dengan Pendekatan Balanced Scorecard
}

\author{
Joko Susilo \\ Universitas Islam Indonesia, Yogyakarta \\ Abstract
}

This paper aims to measure performance measurement of Islamic University of Indonesia by balanced scorecard approach. The balanced scorecard, a performance and strategic management system, has been adopted in for-profit organizations with success and its application in the public sector is explored in this study. Accordingly, the paper uses a survey to measure and analyse a stakeholders's perception about Ull's performance. Respondent of this study are student, employee, and lecturer of this university. The questionares are proposed with four perspective of balanced scorecard approach. The findings of the study indicate how, in different ways, stakeholders are fully satisfy with performance served by UII. Respondent students, in general, have confidence in the quality of the Ull's performance. Respondent employees and lectures are satisfy in perspective of operating efficiency, innovation and change, and employee performance. In the last of this paper, we design model balanced scorecard for UII based on result of survey.

Kaywords: Balanced Scorecard,

Performance Measurement, Stake-

holders.

inerja suatu organisasi dapat dilihat dari

Uberbagai perspektif tergantung dari

karakteristik masing-masing organisasi.

Bagi organisasi bisnis, perspektif keuangan

menjadi faktor yang diunggulkan oleh

organisasi tersebut untuk dijadikan indikator keberhasilan kinerja (Ruben, 1999). Namun demikian, apakah organisasi pendidikan di dalam meningkatkan kinerjanya menjadikan perspektif keuangan sebagai indikator kinerja yang diunggulkan pula? Isu inilah yang akan diteliti dalam penelitian ini selain mencoba menggali perspektif lain yang dimungkinkan menjadi indikator kinerja suatu organisasi pendidikan.

Keberadaan Perguruan Tinggi Swasta (PTS) jelas tidak bisa dipisahkan dengan keberadaan Perguruan Tinggi Negeri (PTN). Peningkatan kinerja dari PTS tidak bisa dilepaskan dari permasalahan-permasalahan yang ada di PTN. PTS dapat belajar dari permasalahan-permasalahan yang ada di PTN di dalam usahanya meningkatkan kinerja organisasi. PTS sebagai mitra organisasi yang sejenis dengan PTN, tentu saja menyadari hal ini. Beberapa dari PTS, berusaha menjadikan masalah-masalah yang dihadapi PTN sebagai indikator yang harus mereka unggulkan dalam peningkatan kinerja organisasi tersebut. Namun apakah sesederhana itu cara untuk meningkatkan kinerja PTS? 
Pengukuran kinerja merupakan proses mencatat dan mengukur pencapaian pelaksanaan kegiatan dalam arah pencapaian visi dan misi organisasi melalui hasil-hasil yang ditampilkan berupa produk, jasa, ataupun suatu proses (Stout, 1993 dalam BPKP, 2000). Konsep Balanced Scorecard (BSC) pada dasarnya merupakan konsep pengukuran kinerja yang menjabarkan visi dan strategi organisasi ke dalam empat perspektif indikator kinerja yaitu perspektif keuangan, pelanggan, proses internal bisnis dan pembelajaran pertumbuhan (Kaplan, 1993; Mulyadi, 2002). Penerapan konsep BSC pada organisasi publik telah banyak dilakukan misalnya pada organisasi kesehatan rumah sakit, organisasi sosial, organisasi pendidikan, kesehatan dan pemeliharaan manula.

Isu-isu yang dijelaskan di atas menjadi motivasi peneliti untuk melakukan penelitian mengenai pengukuran kinerja yang ada dalam PTS khususnya Unervisitas Islam Indonesia (UII) berdasarkan pendekatan BSC dan sekaligus merancang model BSC yang tepat untuk PTS.

\section{Rumusan Masalah dan Tujuan Penelitian}

Berdasarkan latar belakang permasalahan yang telah disebutkan di atas, maka permasalahan yang akan diteliti adalah;

1. Bagaimanakah kinerja dari PTS dalam hal ini UII diukur dengan pendekatan BSC.

2. Apakah terdapat hubungan antara kepuasan mahasiswa dengan proses pendidikan dan administrasi di UII.

3. Apakah terdapat hubungan antara kepuasan mahasiswa dengan pembelajaran dan pertumbuhan di UII.

4. Apakah terdapat hubungan antara pembelajaran dan pertumbuhan dengan proses pendidikan dan administrasi di UII.

5. Bagaimanakah rancangan model BSC yang dapat diterapkan untuk PTS di masa depan.

Adapun tujuan dilakukannya penelitian ini adalah untuk menjawab rumusan masalah di atas.

\section{Kajian Pustaka}

\section{Sistem Pengukuran Kinerja}

Kinerja merupakan kondisi/prestasi yang harus diketahui dan diinformasikan kepada pihak-pihak tertentu untuk mengetahui tingkat pencapaian hasil suatu unit satuan kerja dihubungkan dengan visi yang diemban suatu organisasi serta mengetahui dampak positif dan negatif suatu kebijakan operasional yang diambil. Prestasi ini merupakan tampilan organisasi dalam menjalankan kegiatannya (BPKP, 2000). Kinerja seringkali juga berfokus pada intermediate outcomes seperti kepuasan klien atau perubahan individu atau organisasi dalam jangka pendek (Ningsih, 2002), komponen vital dalam setiap usaha pengelolaan yang berorientasi pada hasil (Suharyani, dkk, 2003).

Pengukuran kinerja merupakan salah satu instrumen yang dipandang efektif sebagai pijakan untuk meningkatkan kinerja secara keseluruhan. Hasil konferensi dari International Conference on Decentralization (ICD) di University of the Philippines merumuskan sistem pengukuran kinerja sebagai sistem penilaian seberapa baik kinerja layanan publik yang diberikan kepada publik berupa barang atau layanan jasa (ICD, 2003). Larry D Stout dalam Performance Measurement Guide sebagaimana yang dikutip oleh BPKP menyatakan bahwa pengukuran kinerja merupakan proses 
Kinerja Layanan Universitas Islam Indonesia Diukur dengan..., Joko Susilo

mencatat dan mengukur pencapaian kegiatan dalam arah pencapaian hasil melalui hasil-hasil yang ditampilkan berupa produk, jasa, ataupun suatu proses.

Mardiasmo (2000) menjelaskan sistem pengukuran kinerja sebagai sistem yang bertujuan untuk membantu manajer publik menilai pencapaian suatu strategi melalui alat ukur finansial dan nonfinansial. Sementara, Ulupui (2002) mengartikan pengukuran kinerja sebagai pengukuran kemajuan secara periodik terhadap tujuantujuan yang bersifat jangka panjang dan pendek yang nyata dan pelaporan hasilhasilnya untuk para pengambil keputusan sebagai suatu upaya untuk peningkatan kinerja program.

Alasan diperlukannya pengukuran kinerja dijelaskan oleh Ningsih (2000) yang mengutip dari Neely (1999) meliputi; adanya perubahan lingkungan, meningkatnya persaingan, adanya usaha-usaha perbaikan yang spesifik, adanya penghargaan nasional dan internasional, adanya perubahan peran organisasi profesi, adanya perubahan permintaan dari pihak eksternal, dan kemajuan teknologi informasi. Bastian (2001) menegaskan bahwa di dalam menyusun tujuan pengukuran kinerja suatu unit organisasi publik, maka tujuan tersebut harus fokus pada kualitas layanan publik itu sendiri.

Terkait dengan tujuan pengukuran kinerja di atas, maka stakeholders dapat menggunakan informasi pengukuran kinerja untuk meningkatkan pemahaman mereka terhadap faktor-faktor yang mempengaruhi kinerja, dan untuk mendukung fungsi pokok dari manajemen seperti penyusunan skala prioritas, manajemen strategik, yang mengandung siklus perencanaan, penganggaran, pengawasan, dan pelaporan (ICB, 2003).
Dari penjelasan di atas dapat disimpulkan bahwa sistem pengukuran kinerja merupakan salah satu instrumen yang dipandang efektif sebagai pijakan untuk meningkatkan kinerja secara keseluruhan. Kendati keefektifan itu sendiri masih menjadi bahan diskusi, upaya-upaya penyempurnaan sistem pengukuran kinerja masih terus dilakukan. Tujuannya adalah ditemukannya suatu metode pengukuran kinerja yang secara efektif meningkatkan kinerja pemerintah daerah khususnya dalam penyelenggaraan pelayanan publik dan meningkatkan fungsi kontrol publik.

\section{Karakteristik Balanced Scorecard}

Pengukuran kinerja didefinisikan sebagai pengukuran kemajuan secara periodik terhadap tujuan-tujuan yang bersifat jangka panjang dan jangka pendek yang nyata dan pelaporan hasil-hasilnya untuk para pengambil keputusan sebagai suatu upaya untuk meningkatkan kinerja program (Ulupui, 2002). Pengukuran kinerja yang efektif memiliki sejumlah aplikasi khusus. Aplikasi ini digunakan untuk memformulasikan anggaran, mengalokasikan sumber daya, memotivasi pegawai, mengingkatkan servis dan memfasilitasi perubahan informasi antara masyarakat dan pemerintah. Pengukuran kinerja dapat digunakan untuk self-assesment dan improvement bukan hanya audit and monitoring (Thomas, 1995).

Balanced Scorecard (BSC) adalah suatu konsep pengukuran kinerja yang mengakomodasikan berbagai indikator kinerja ke dalam suatu konsep yang kemudian digunakan untuk mengukur kinerja suatu organisasi (Kaplan dan Norton, 1996). BSC tidak saja merupakan sistem pengukuran kinerja tetapi BSC juga merupakan management system yang memungkinkan 
organisasi untuk mengklarifikasi visi dan strategi serta menerjemahkan visi dan misi tersebut ke dalam kegiatan organisasi (Averson, 1998). Balanced scorecard juga merupakan metode terstruktur untuk mengkomunikasikan pengukuran dan target. Metode ini digunakan sebagai alat untuk mengelola dan mengkomunikasikan informasi finansial dan non finansial (Shaikh, 2004). Indikator kinerja berupa kinerja finansial yang selama ini dinilai merupakan faktor yang paling penting, sekarang sudah kurang relevan lagi digunakan sebagai dasar dalam pengambilan keputusan (Ruben, 1999). Indikator non finansial menjadi suatu alternatif baru dalam menilai kinerja suatu organisasi. Indikator finansial maupun non finansial seharusnya tidak dilihat sebagai sesuatu yang saling menggantikan, keduanya seharusnya merupakan suatu kesatuan yang dapat mencerminkan kinerja organisasi secara keseluruhan. BSC mengakomodir kedua macam indikator ini baik finansial maupun non finansial.

Kaplan (1993) menjabarkan bahwa untuk mendesain suatu BSC bagi suatu organisasi harus memiliki tiga karakteristik penting yaitu;

- BSC dipresentasikan dalam suatu dokumen yang berisi indikator-indikator yang lengkap mengenai kinerja perusahaan

- Dokumen ini merupakan dokumen singkat yang memuat secara garis besar indikator-indikator yang lengkap mengenai kinerja perusahaan

- Indikator BSC kemudian dikelompokkan dalam empat perspektif yaitu perspektif finansial, konsumen, proses bisnis internal dan pertumbuhan.

Teknik pengukuran kinerja balanced scorecard ini banyak dikembangkan oleh berbagai organisasi dewasa ini karena dinilai lebih komprehensif. Dengan balanced scorecard, kinerja organisasi diukur tidak hanya didasarkan pada aspek finansialnya saja, tetapi juga aspek non finansial. Balanced scorecard adalah alat manajemen (management tool) yang menerjemahkan visi, misi dan strategi organisasi ke dalam satu set pengukuran kinerja komprehensif untuk menghasilkan kerangka pengukuran kinerja organisasi melalui beberapa perspektif: finansial, customer, proses bisnis internal, serta pembelajaran dan pertumbuhan. Dari tiap-tiap perspektif, harus ditunjukkan tujuan (objectives), ukuranukuran (measures) kinerja yang dipergunakan, target yang akan dicapai, dan inisiatif stratejik yang harus dilakukan untuk mencapai target yang telah ditetapkan sekaligus untuk mencapai misi organisasi. Penjabaran visi dan misi dalam suatu rencana stratejik dilakukan dalam empat persprektif yang meliputi keuangan, pelanggan, proses bisnis internal, serta pembelajaran dan pertumbuhan, seperti digambarkan dalam Tabel 1.

\section{Pengembangan Hipotesis}

Indikator kinerja pada organisasi pendidikan tinggi pada umumnya sulit untuk direncanakan dan tidak secara umum diterima. Namun pada umumnya terdapat tiga indikator kinerja pada organisasi ini (Jowett dan Rothwell, 1988:54):

(i) Indikator kinerja internal meliputi pangsa pasar pengguna lulusan, jumlah lulusan dan gelar, daya tarik mahasiswa master dan doktor, tingkat keberhasilan dan waktu yang diperlukan untuk gelar yang lebih tinggi, daya tarik dana penelitian, dan kualitas pengajaran. 
Kinerja Layanan Universitas Islam Indonesia Diukur dengan..., Joko Susilo

Tabel 1

Perspektif Keuangan Keuntungan, ROI Perspektif Pelanggan n dan Norton

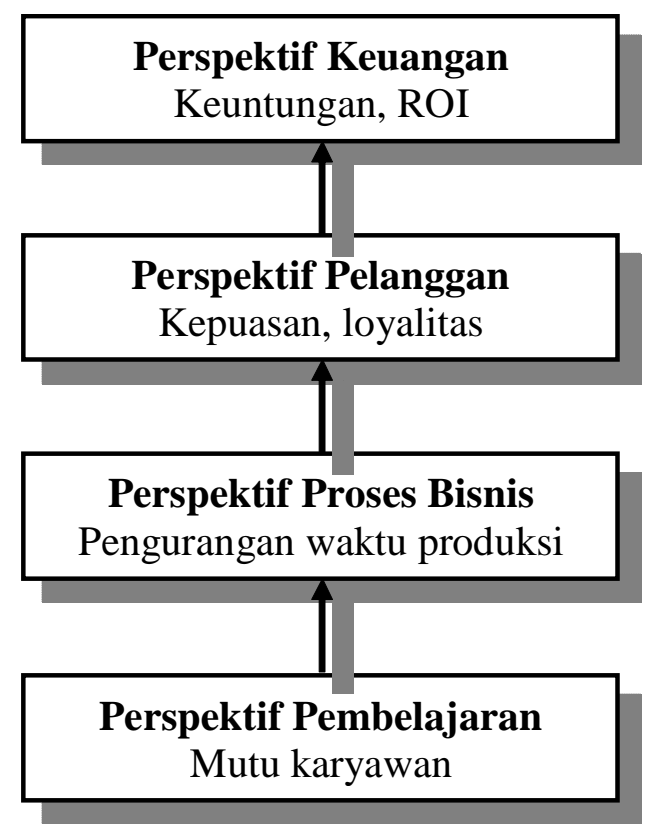

Sumber: Kaplan dan Norton (1996)

(ii) Indikator kinerja eksternal meliputi penerimaan lulusan di lapangan kerja, tujuan pertama lulusan, reputasi yang dinilai dari pihak luar, publikasi pada dosen dan surat penghargaan yang diperolehnya, paten, penemuan, konsultan, keanggotaan profesi, hadiah dan medali dari lembaga akademik, dan makalah dalam konferensi.

(iii) Indikator kinerja operasi meliputi biaya per unit, rasio mahasiswa dan dosen, ukuran kelas, pilihan mata kuliah yang tersedia, kelebihan beban kerja dosen, stok buku yang tersedia di perpustakaan, dan jumlah sarana komputer yang tersedia.

Chang dan Chow (1999) menjelaskan dalam artikelnya bahwa BSC merupakan alat potensial yang mendukung perubahan dan perbaikan berkelanjutan dalam dunia pendidikan. Ruben (1999) dalam artikelnya menyebutkan ada lima indikator dalam menyusun suatu misi, visi dan tujuan organisasi pendidikan tinggi yang dia istilahkan dengan "dashboard indicator". Kelima indikator tersebut adalah; teaching/ learning, scholarship/research, service/outreach, workplace satisfaction, dan financial.

Berdasar pada kajian pustaka dan landasan teori yang telah dibahas di atas maka dalam penelitian ini dikembangkan hipotesis penelitian sebagai berikut;

H1: Terdapat hubungan antara kepuasan pelanggan (mahasiswa) dengan proses pendidikan dan administrasi

H2: Terdapat hubungan antara kepuasan pelanggan (mahasiswa) dengan pembelajaran dan pertumbuhan

H3: Terdapat hubungan antara proses pendidikan dan administrasi dengan pembelajaran dan pertumbuhan 


\section{Metodologi Penelitian Populasi Penelitian dan Teknik Pengambilan Data}

Populasi penelitian ini adalah seluruh dosen, karyawan dan mahasiswa di UII. Sampel yang digunakan dalam penelitian ini adalah dosen, karyawan dan mahasiswa UII yang diambil berdasarkan metode convenience sampling, yakni teknik pengambilan sampel dimana peneliti dapat mengambil sampel dimanapun yang paling mudah ditemui (Cooper \& Emory, 1995). Teknik ini digunakan mengingat keterbatasan waktu.

Kuesioner untuk mahasiswa dibuat terdiri dari dua bagian, yang pertama pertanyaan mengenai kepuasan mahasiswa terhadap perguruan tinggi tempat mereka belajar yang terdiri dari lima item pernyataan. Bagian yang kedua dari kuesioner adalah pernyataan mengenai proses pendidikan atau proses belajar mengajar dan proses administrasi yang terdiri tiga belas item peryataan.

Kuesioner untuk dosen dan karyawan terdiri dari satu bagian pernyataan yang sama yakni pernyataan yang mengukur tentang perspektif pembelajaran dan pertumbuhan (learning dan growth). Semua kuesioner dibuat dengan menggunakan skala likert satu sampai lima, dimana skala 1 (sangat tidak setuju), 2 (tidak setuju), 3 (netral), 4 (setuju) dan 5 (sangat setuju).

Data sekunder diperoleh dari laporan tahunan rektor pada dies natalis tahun 2004 dan tahun 2005. Data yang berhubungan dengan penelitian ini antara lain data tentang perspektif keuangan perguruan tinggi, karena yang menjadi objek penelitian adalah perguruan tinggi swasta maka data yang tersedia tentang pelaksanaan anggaran. Dari 200 kuisioner yang dikirimkan, sebanyak 183 kuisoner $(91,50 \%)$ diterima kembali. Dari 183 kuisioner yang diterima tersebut, semuanya bisa diolah. Jadi jumlah data yang bisa diolah sebesar 183 kuisioner (100\%) dari total kuesioner.

\section{Uji Validitas dan Reliabilitas}

Dari hasil uji validitas diketahui bahwa semua item pernyataan adalah valid dengan tingkat keyakinan $99 \%$ atau signifikansi $1 \%$ kecuali untuk item pertanyaan satu dan dua dalam proses bisnis internal yang valid dengan tingkat keyakinan 95\%. Karena semua item pernyataan valid, maka semua item tersebut dapat diikutkan dalam pengujian reliabilitas.

Untuk variabel persepsi/penilaian mahasiswa terhadap pelayanan yang diberikan oleh UII, hasil pengujian reliabilitas menunjukkan angka Cronbach Alpha sebesar 0,7224 . Untuk variabel persepsi/ penilaian mahasiswa terhadap proses bisnis internal yang ada dalam UII, hasil pengujian reliabilitas menunjukkan angka Cronbach Alpha sebesar 0,8433 . Sedang untuk variabel persepsi/penilaian dosen dan karyawan terhadap perspektif pembelajaran dan pertumbuhan yang ada dalam UII, hasil pengujian reliabilitas menunjukkan angka Cronbach Alpha sebesar 0,8309. Semua hasil uji menunjukkan nilai yang lebih besar dari batas yang disebutkan Nunnaly yaitu 0,6 . Jadi, dapat disimpulkan bahwa ketiga instrumen tersebut bersifat reliabel.

\section{Uji Rata-rata Penilaian Responden}

Pengukuran rata-rata instrumen variabel penilaian responden terhadap informasi pengukuran kinerja di UII diperlukan untuk menjelaskan secara detail sejauh mana responden menilai informasi-informasi tersebut. Kriteria sejauh mana informasi pengukuran kinerja BSc dapat memenuhi penilaian responden atas kualitas kinerja UII dilihat dari nilai rata-rata masing-masing 
Kinerja Layanan Universitas Islam Indonesia Diukur dengan..., Joko Susilo

instrumen penilaian responden. Jika nilai rata-rata suatu instrumen lebih kecil dari 2,5 maka ini menunjukkan bahwa informasi tersebut tidak memenuhi kriteria penilaian tersebut. Sedang jika nilai rata-rata suatu instrumen lebih besar dari 2,5 maka ini berarti informasi kinerja Ull sudah memenuhi kriteria penilaian tersebut. Berikut ini penjelasan detail masing-masing instrumen penilaian responden terhadap informasi kinerja UII.
Dari tabel 2, dapat disimpulkan bahwa mahasiswa sebagai pelanggan dari UII tersebut terpenuhi kebutuhan (terpuaskan) dengan kinerja UII melalui empat pernyataan yang mengukur tentang kepuasan mahasiswa akan kinerja UII. Rata-rata responden menjawab di atas nilai netral yakni 3 yang berarti bahwa mereka setuju bahwa kualitas layanan akademik kepada mahasiswa adalah sudah baik. Hanya saja yang menjadi catatan disini adalah penilaian mahasiswa terhadap kualitas layanan

Tabel 2

Penilaian Kepuasan Mahasiswa Terhadap Kinerja UII

\begin{tabular}{|r|l|}
\hline Mean & \multicolumn{1}{|c|}{ Pernyataan } \\
\hline 3,16 & $\begin{array}{l}\text { Kualitas jasa yang diberikan oleh dosen di Ull ini dalam penguasaan materi maupun praktik } \\
\text { sangat memuaskan }\end{array}$ \\
\hline 2,95 & Kualitas jasa yang diberikan oleh karyawan di Ull ini memuaskan \\
\hline 3,22 & $\begin{array}{l}\text { Kualitas jasa yang diberikan oleh Ull ini dalam hal penyediaan fasilitas pendidikan sangat } \\
\text { memuaskan }\end{array}$ \\
\hline 3,21 & $\begin{array}{l}\text { Kualitas jasa yang diberikan oleh UII dari segi dosen, karyawan, tenaga administrasi maupun } \\
\text { fasilitas memuaskan }\end{array}$ \\
\hline
\end{tabular}

Tabel 3

Penilaian Mahasiswa Terhadap Proses Bisnis Internal UII

\begin{tabular}{|r|l|}
\hline \multicolumn{1}{|c|}{ Mean } & \multicolumn{1}{|c|}{ Pernyataan } \\
\hline 3,66 & Sebagian besar dosen berkualifikasi S2 dan atau S3 \\
\hline 3,26 & Sebagian besar dosen mengajar di berbagai tempat selain di UII ini \\
\hline 4,12 & Sebagian besar dosen berpenampilan rapi dan sopan \\
\hline 3,78 & Sebagian besar dosen bersikap ramah dan sopan kepada mahasiswa \\
\hline 3,24 & Tersedia fasilitas foto kopi yang murah \\
\hline 4,01 & Tersedia tempat parkir yang cukup dan aman \\
\hline 4,24 & $\begin{array}{l}\text { Perkuliahan dilakukan dengan menggunakan peralatan modern (OHP, in-focus, audio visual, } \\
\text { dan lain-lain) }\end{array}$ \\
\hline 3,35 & $\begin{array}{l}\text { Aspirasi mahasiswa ditanggapi secara baik oleh UII, misalnya masalah-masalah yang } \\
\text { menyangkut kebijakan UII }\end{array}$ \\
\hline 4,01 & $\begin{array}{l}\text { Tersedia fasilitas penunjang kegiatan belajar mengajar berupa buku dan sejenisnya di } \\
\text { perpustakaan }\end{array}$ \\
\hline 3,64 & Alumni dilayani dengan baik apabila berurusan dengan UII \\
\hline 3,86 & Perpustakaan sudah memanfaatkan teknologi modern seperti computer \\
\hline 3,26 & Pelayanan yang diberikan oleh karyawan cepat dan professional \\
\hline 3,99 & Karyawan berpenampilan rapi dan sopan \\
\hline
\end{tabular}


UNISIA, Vol. XXX No. 64 Juni 2007

Tabel 4

Penilaian Dosen dan Karyawan terhadap Perspektif Pembelajaran dan Pertumbuhan di UII

\begin{tabular}{|r|l|}
\hline \multicolumn{1}{|c|}{ Mean } & \multicolumn{1}{c|}{ Pernyataan } \\
\hline 3,518072 & Karyawan dilibatkan dalam setiap proses pengambilan keputusan \\
\hline 3,698795 & Lingkungan kerja di Ull ini kondusif untuk melaksanakan tugas \\
\hline 3,807229 & Fasilitas yang tersedia di kantor sudah modern dan menunjang kelancaran tugas \\
\hline 3,60241 & Batas-batas wewenang dan tugas di tempat kerja sudah cukup jelas \\
\hline 3,846988 & Karyawan diberikan kesempatan cukup untuk mengikuti kursus, penataran, maupun diklat \\
\hline 3,819277 & Ada pengakuan atas hasil baik kerja karyawan \\
\hline 4,072289 & Tersedia sistem informasi yang mudah diakses yang mendukung kelancaran tugas \\
\hline 3,963855 & Dukungan diberikan oleh atasan untuk pengembangan sumber daya manusia sangat baik \\
\hline
\end{tabular}

Tabel 5

Hasil Uji Korelasi Antar Variabel

Correlations

\begin{tabular}{|ll|r|r|r|}
\hline & & LEARNGRO & KEPMHS & BISINTER \\
\hline LEARNGRO & Pearson Correlation & 1 &,- 109 &, 117 \\
& Sig. (2-tailed) &, &, 327 &, 293 \\
& $\mathrm{~N}$ & 83 & 83 & 83 \\
\hline KEPMHS & Pearson Correlation &,- 109 & 1 &, $331^{\star}$ \\
& Sig. (2-tailed) &, 327 &, &, 001 \\
& $\mathrm{~N}$ & 83 & 100 & 100 \\
\hline BISINTER & Pearson Correlation &, 117 &, $331^{\star *}$ & 1 \\
& Sig. (2-tailed) &, 293 &, 001 &, \\
& $\mathrm{~N}$ & 83 & 100 & 100 \\
\hline
\end{tabular}

**. Correlation is significant at the 0.01 level (2-tailed).

karyawan nilainya tidak setinggi tiga penilaian lainnya, sehingga kesimpulan umum dari perspektif kepuasan mahasiswa untuk kualitas Iayanan akademik UII, mahasiswa rata-rata sudah puas terhadap layanan kinerja akademik.

Dari hasil analisa tabel 3, disimpulkan bahwa penilaian mahasiswa terhadap proses bisnis internal adalah baik. Sebagian besar rata-rata penilaian mahasiswa di atas poin 3.
Hasil dari analisa tabel 4, dapat disimpulkan bahwa secara umum, dosen dan karyawan menilai bahwa perspektif pembelajaran dan pertumbuhan di Ull sudah bagus terutama penilaian terkait dengan sistem informasi yang ada di UII.

\section{Uji Korelasi}

Hasil pengujian korelasi terhadap variabel-variabel tersebut dapat dilihat dalam tabel 5. 
Kinerja Layanan Universitas Islam Indonesia Diukur dengan..., Joko Susilo

Dari hasil analisis tabel 5 menunjukkan bahwa untuk variabel proses bisnis intern dan kepuasan mahasiswa mempunyai hubungan yang signifikan yakni sebesar 0,331 pada tingkat kepercayaan $99 \%$. Dengan demikian, $\mathrm{H} 1$ diterima yang mengindikasikan bahwa terdapat hubungan antara proses pendidikan dan administrasi sebagai cerminan proses bisnis intern dengan kepuasan mahasiswa.

Untuk hubungan antara variabel kepuasan mahasiswa dengan perspektif pembelajaran dan pertumbuhan, hasil uji korelasi menunjukkan tidak adanya hubungan antar dua variabel tersebut. Dengan demikian, dari uji korelasi kedua variable ini, dapat disimpulkan bahwa $\mathrm{H} 2$ tidak dapat diterima yang berarti, tidak terdapat hubungan yang saling mempengaruhi antara kepuasan mahasiswa dengan pembelajaran dan pertumbuhan institusi.

Hasil uji korelasi Pearson untuk H3 menunjukkan bahwa, angka korelasi antara variabel pertumbuhan dan pembelajaran dengan proses bisnis intern tidak signifikan. Artinya, tidak ada hubungan yang kuat antara variabel pertumbuhan dan pembelajaran dengan variabel proses bisnis intern. Sehingga H3 juga tidak dapat diterima.

Kesimpulan dari hasil uji korelasi ketiga variabel tersebut semakin menguatkan penelitian yang dilakukan oleh Pujiningsih (2001). Hasil uji korelasi yang dilakukan oleh Pujiningsih terhadap ketiga variable di lingkungan Perguruan Tinggi Negeri, menunjukkan hasil yang sama dengan yang peneliti lakukan sekarang. Dari ketiga hipotesis, hanya variabel kepuasan mahasiswa saja yang menunjukkan hubungan yang kuat dengan variabel proses bisnis intern. Untuk korelasi antara variabel kepuasan mahasiswa dengan pembelajaran dan pertumbuhan, dan korelasi antara variabel pembelajaran dan pertumbuhan dengan variabel proses bisnis intern, menunjukkan korelasi yang lemah/tidak ada hubungan.

\section{Analisa Perspektif Keuangan UII}

Dari data keuangan yang dikutip dari Laporan Rektor UII akhir tahun jabatan 2006 mengenai alokasi dana UII, dapat disimpulkan bahwa jumlah penerimaan dana yang masuk ke Ull dari tahun 2003/2004 ke tahun 2004/2005 mengalami kenaikan sebesar Rp 8.838.411.268,-- atau naik sekitar $20 \%$. Demikian juga dengan jumlah pengeluaran dana yang dikeluarkan oleh UII dari tahun 2003/2004 ke tahun 2004/2005 mengalami kenaikan sebesar $\mathrm{Rp}$ 3.093.761.948,-- atau sebesar 7\%.

Salah satu ukuran keberhasilan kinerja keuangan adalah adanya efektivitas dari penggunaan dana meliputi efisiensi dan keefektifan penggunaan dana serta jumlah sisa dana untuk kepentingan pengembangan (Jowett dan Rothwell,1988). Dari data keuangan di atas, meskipun persentase pengeluaran dana mengalami kenaikan sebesar $7 \%$, tetapi kenaikan pengeluaran ini diimbangi atau bahkan ditutup dengan adanya kenaikan penerimaan dana sebesar $20 \%$. Sehingga dari sini, terjadi efisiensi dan efektivitas penggunaan dana oleh UII. Bahkan, jika di tahun 2003/2004, UII mengalami defisit sebesar Rp 913.769.010,- maka pada tahun 2004/2005, UII justru mengalami surplus atau terdapat sisa dana untuk kepentingan pengembangan akademik lain sebesar Rp 4.830.880.310,-. Suatu peningkatan dana yang sangat berbeda dengan tahun sebelumnya.

Data dari yayasan UII yakni Badan Wakaf UII menunjukkan bahwa total dana 
yang diterima UII melalui yayasan sebesar 94,91\% masih mengandalkan penerimaan dari mahasiswa, sedangkan sisanya masing-masing $1,92 \%$ adalah dari penerimaan bank, 1,57\% pendapatan lainlain, 0,05\% dari penjualan aktiva tetap, 0,79\% dari pendapatan hibah, $0,73 \%$ dari penggunaan sisa dana dan pendapatan warnet sebesar $0,03 \%$.

Untuk serapan anggaran, dari hasil penelitian diketahui bahwa, selain anggaran pendapatan lain-lain, penggunaan sisa dana, dan pendapatan warnet, terjadi selisih anggaran yang menguntungkan (favorable). Selisih lebih ini terjadi karena dana yang terealisasi lebih besar dari yang dianggarkan. Secara kumulatif, realisasi penerimaan dana lebih besar dari yang dianggarkan.

Dari data keuangan yang ada, persentase penggunaan dana oleh UII dialokasikan ke bidang akademik mulai dari karyasiswa, pengembangan fakultas, administrasi akademik, kegiatan pusat/ lembaga, gaji staf pengajar, dan biaya akademik yang lain masing-masing untuk tahun 2003/2004 sebesar 51\% dan tahun 2004/2005 sebesar 55\%,sehingga untuk dua tahun anggaran ini, pengeluaran bidang akademik mengalami peningkatan sebesar $15 \%$.

Untuk pengeluaran bidang administrasi keuangan dan umum yang mencakup gaji pegawai, biaya listrik, biaya telepon, biaya air, biaya kegiatan, biaya pemeliharaan aktiva dan biaya administrasi lain, persentase penggunaan dananya adalah sebesar 40\% untuk tahun 2003/2004 dan $35 \%$ untuk tahun 2004/2005. Hal ini berarti, penggunaan dana untuk administrasi keuangan dan umum ini mengalami penurunan yang signifikan dari yakni sebesar $7 \%$. Sedang penggunaan dana lainnya adalah untuk kegiatan kemahasiswaan seperti kegiatan lembaga kemahasiswaan, pengembangan dan pembinaan mahasiswa, pesantren mahasiswa dan humas, masingmasing persentasenya 3\%. Meskipun sama, justru penggunaan dana ini mengalami penurunan sebesar $2 \%$ dari tahun 2003 / 2004 ke tahun 2004/2005. Alokasi dana lain adalah pengeluaran khusus yang terdiri dari biaya konsultan, reorganisasi dan persiapan perpindahan gedung Rektorat sebesar 6\% untuk tahun 2003/2004 dan 7\% untuk tahun 2004/2005.

\section{Pembuatan Model Pengukuran Kinerja Bsc Untuk UII}

Pembuatan model pengukuran kinerja BSc dimulai dengan model BSc untuk tingkat perusahaan (corporate scorecard) kemudian diterjemahkan ke dalam BSC unit bisnis (business unit scorecard), diterjemahkan lagi menjadi BSC departemen atau unit-unit pelayanan (department scorecard), dan disebarluaskan menjadi BSc tim atau individu (team/individual scorecard) (Gaspersz, 2005). Begitu juga dengan UII, pembuatan model BSc juga harus dimulai dari tingkat tertinggi yakni Rektorat, kemudian diterjemahkan ke dalam unit bisnis seperti fakultas, kemudian diterjemahkan oleh masing-masing program studi, dan kemudian disebarluaskan oleh team atau individu-individu di masing-masing unit tersebut.

Masing-masing unit harus mampu menerjemahkan sistem manajemen yang terintegrasi di dalamnya konsep BSc, mulai dari perspektif pembelajaran dan pertumbuhan, perspektif proses bisnis internal, perspektif pelanggan dan perspektif keuangan.

Dengan dasar hasil uji statistik kuesioner dan dari landasan teori yang ada pada penjelasan sebelumnya, disusunlah 
Kinerja Layanan Universitas Islam Indonesia Diukur dengan..., Joko Susilo

sistem manajemen untuk UII dimulai dari perspektif pembelajaran dan pertumbuhan sampai ke perspektif keuangan.

Tahap-tahap teknis dalam pembuatan model dan penerapannya untuk UII adalah sebagaimana Tabel 6.

\section{Penjabaran visi, misi dan tujuan UII ke dalam BSC}

\section{Menjabarkan misi strategi ke dalam misi masing-masing unit strategis}

Dari visi dan misi universitas tadi dibreakdown ke dalam masing-masing unit strategis sebagaimana yang telah dijelaskan di depan. Untuk itu perlu diketahui dulu departemen/unit-unit yang ada di bawah UII. Dari data sumber daya yang ada, dibuat rincian rumusan visi dan misi direktorat, misalkan Direktorat Akademik-Divisi Administrasi Akademik.

Dari penjabaran misi strategis universitas ke misi dibawahnya, langkah berikutnya adalah mengidentifikasi pihak-pihak terkait dengan misi divisi tersebut dikaitkan dengan program kerja/teknis. Teknis pengidentifikasiannya adalah sebagaimana Tabel 9.

\section{Membuat formulir/kartu BSC diintegrasikan dengan analisa SWOT}

Tahap berikutnya adalah membuat formulir/kartu BSc untuk temuan-temuan di lapangan mencakup hasil survey, observasi dan wawancara. Temuan-temuan tersebut dianalisa dengan pendekatan SWOT (Strength, Weakness, Opportunity, Treath).

Tabel 6

Sistem Manajemen Integrasi Perspektif BSc

\begin{tabular}{|c|c|c|c|}
\hline Aspek & $\begin{array}{c}\text { Faktor } \\
\text { Keberhasilan } \\
\text { Kritis }\end{array}$ & $\begin{array}{c}\text { Sasaran-sasaran } \\
\text { dan Target }\end{array}$ & Indikator-indikator Kinerja \\
\hline \multirow[t]{3}{*}{ Keuangan } & Kesejahteraan & 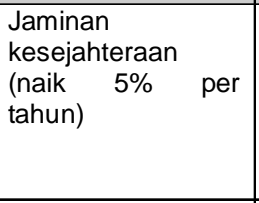 & $\begin{array}{l}\text { - Jumlah sumbangan permanent dari yayasan } \\
\text { - Jumlah dana dari pihak luar, seperti alumni } \\
\text { - dan institusi lain } \\
\text { - Jumlah dana dari SPP mahasiswa } \\
\text { - } \begin{array}{l}\text { Perbandingan jumlah yang diberikan } \\
\text { kampus dengan institusi sederajat }\end{array} \\
\end{array}$ \\
\hline & Keberhasilan & $\begin{array}{l}\text { Keefektifan } \\
\text { penggunaan dana } \\
\text { (naik 10\%) }\end{array}$ & $\begin{array}{l}\text { - } \text { Efisiensi dan keefektifan penggunaan dana } \\
\text { - Jumlah sisa dana untuk kepentingan } \\
\text { pengembangan } \\
\text { - Realisasi anggaran }\end{array}$ \\
\hline & Keberlanjutan & $\begin{array}{l}\text { Jaminan } \\
\text { kelangsungan } \\
\text { proses pendidikan } \\
\text { (jumlah pendaftar } \\
\text { naik } 10 \% \text { per } \\
\text { tahun, } \\
\text { permohonan } \\
\text { dispensasi turun } \\
50 \% \text { per tahun) }\end{array}$ & 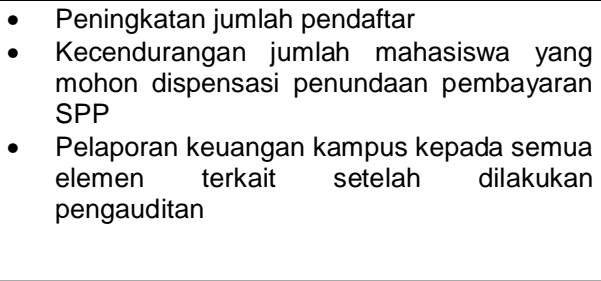 \\
\hline $\begin{array}{l}\text { Pembelajaran } \\
\text { Pertumbuhan }\end{array}$ & dan & 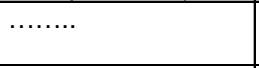 & \\
\hline $\begin{array}{l}\text { Bisnis } \\
\text { Internal }\end{array}$ & & $\ldots \ldots \ldots$ & \\
\hline Pelanggan & & & \\
\hline
\end{tabular}


Tabel 7

Perumusan Visi dan Misi UII

\begin{tabular}{l}
\hline \multicolumn{3}{|c|}{ HASIL RUMUSAN VISI DAN MISI UNIVERSITAS ISLAM INDONESIA } \\
\hline \multicolumn{1}{|c|}{ DEPARTEMEN } \\
\hline-
\end{tabular}

Tabel 8

Perumusan Visi dan Misi Direktorat Akademik-Divisi Administrasi Akademik

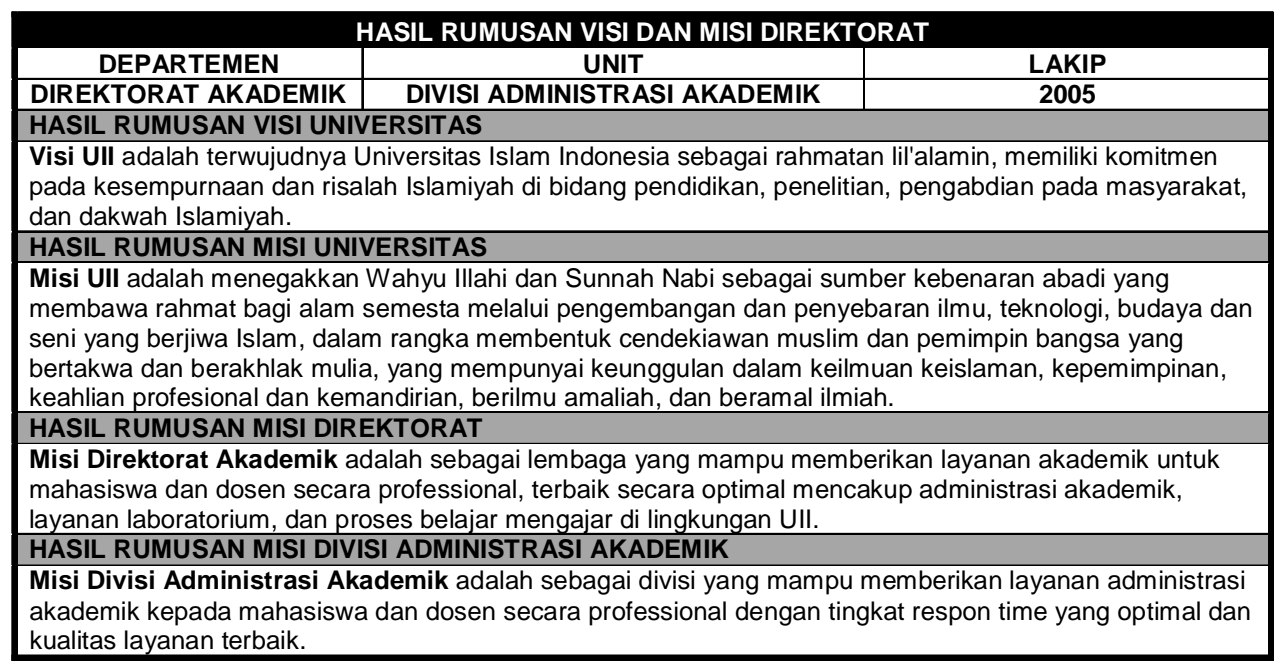


Kinerja Layanan Universitas Islam Indonesia Diukur dengan..., Joko Susilo

Tabel 9

Identifikasi Pihak Terkait Misi Direktorat Akademik-Divisi Administrasi Akademik

\begin{tabular}{|c|c|c|c|c|c|c|c|c|c|c|c|c|c|}
\hline \multicolumn{14}{|c|}{ UNIT } \\
\hline \multicolumn{2}{|l|}{$\begin{array}{l}\text { DEPARIEIMEN } \\
\text { DIREKTORAT } \\
\text { AKADEMIK }\end{array}$} & \multicolumn{7}{|c|}{$\begin{array}{c}\text { UNIT } \\
\text { DIVISI ADMINISTRASI AKADEMIK }\end{array}$} & \multicolumn{5}{|c|}{2005} \\
\hline \multicolumn{14}{|c|}{$\begin{array}{l}\text { Memberikan layanan administrasi akademik kepada mahasiswa dan dosen secara professional } \\
\text { dengan tingkat respon time yang optimal dan kualitas layanan terbaik. }\end{array}$} \\
\hline \multirow[t]{2}{*}{ STAKEHOLDERS } & \multicolumn{10}{|c|}{\begin{tabular}{|l|l|} 
KEGIATAN UTAMA \\
\end{tabular}} & \multicolumn{3}{|c|}{ PERAN } \\
\hline & 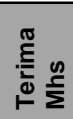 & 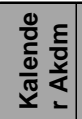 & 丞 & 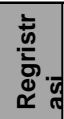 & $\underline{E}$ & 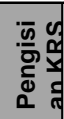 & 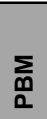 & $\begin{array}{l}\frac{\pi}{0} \\
\stackrel{0}{3} \\
3\end{array}$ & $=\frac{\frac{1}{\frac{\pi}{3}}}{3}$ & 忘 & 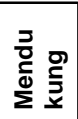 & 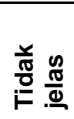 & 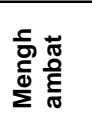 \\
\hline Mahasiswa & & & & $\checkmark$ & $\checkmark$ & $\checkmark$ & $\checkmark$ & $\checkmark$ & $\checkmark$ & $\checkmark$ & & & $\checkmark$ \\
\hline Dosen & $\checkmark$ & $\checkmark$ & $\checkmark$ & & & & $\checkmark$ & $\checkmark$ & & $\checkmark$ & $\checkmark$ & & \\
\hline Karyawan & $\checkmark$ & $\checkmark$ & $\checkmark$ & $\checkmark$ & $\checkmark$ & $\checkmark$ & $\checkmark$ & $\checkmark$ & $\checkmark$ & $\checkmark$ & $\checkmark$ & & \\
\hline
\end{tabular}

Tabel 10

Hasil Analisa SWOT dan BSc untuk Direktorat Akademik-Divisi Administrasi Akademik

\begin{tabular}{|c|c|c|c|c|c|c|c|c|c|c|}
\hline \multirow{2}{*}{\multicolumn{10}{|c|}{$\begin{array}{l}\text { HASIL TEMUAN LINGKUNGAN ORGANISASI DIREKTORAT } \\
\text { DEPARTFMEN }\end{array}$}} & \\
\hline & & \multirow{2}{*}{\multicolumn{8}{|c|}{$\begin{array}{r}\text { LAKIP } \\
2005\end{array}$}} & \\
\hline DIREKTORAT AKADEMIK & DIVISI ADMINISTRASI & & & & & & & & & \\
\hline \multirow{2}{*}{\multicolumn{2}{|c|}{ RUMUSAN TEMUAN }} & \multicolumn{4}{|c|}{ ANALISA SWOT } & \multicolumn{4}{|c|}{ ANALISA BSC } & \\
\hline & & $\infty$ & 3 & 0 & $\vdash$ & $\overrightarrow{\underline{u}}$ & $\Delta$ & 足 & త & \\
\hline \multirow{2}{*}{\multicolumn{2}{|c|}{$\begin{array}{l}\text { Kualitas SDM divisi } \\
\text { Profesionalitas }\end{array}$}} & & $\checkmark$ & & & & & & $\checkmark$ & \\
\hline & & & & & $\checkmark$ & & & & $\checkmark$ & \\
\hline \multicolumn{2}{|l|}{ Kurikulum } & & & $\checkmark$ & & & & & $\checkmark$ & \\
\hline \multicolumn{2}{|c|}{ Link and Match } & & $\checkmark$ & & & & & & $\checkmark$ & \\
\hline \multirow{2}{*}{\multicolumn{2}{|c|}{$\begin{array}{l}\text { Kualitas layanan jasa dan respon time of services } \\
\text { Kepercavaan terhadap PBM }\end{array}$}} & & $\checkmark$ & & & & & $\checkmark$ & & \\
\hline & & $\checkmark$ & & & & & & $\checkmark$ & & \\
\hline \multicolumn{2}{|c|}{ Kualitas perangkat pendukung PBM } & $\checkmark$ & & & & & & $\checkmark$ & & \\
\hline \multicolumn{2}{|c|}{ Lulusan yang unggul } & & $\checkmark$ & & & & $\checkmark$ & & & \\
\hline \multicolumn{2}{|l|}{ Kualitas PBM } & $\checkmark$ & & & & & $\checkmark$ & & & \\
\hline \multicolumn{2}{|c|}{ Hubungan mahasiswa dengan dosen } & $\checkmark$ & & & & & $\checkmark$ & & & \\
\hline \multicolumn{2}{|c|}{ Jaminan Kesejahteraan } & & $\checkmark$ & & & $\checkmark$ & & & & \\
\hline \multirow{2}{*}{\multicolumn{2}{|c|}{ 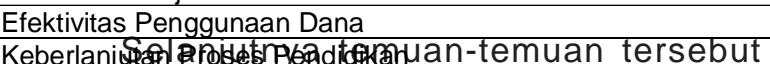 }} & $\checkmark$ & & & & $\checkmark$ & & & & \\
\hline & & & & & & & & & 154 & kritis tiap \\
\hline \multicolumn{2}{|c|}{ 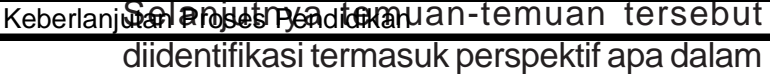 } & \multirow{2}{*}{\multicolumn{9}{|c|}{$\begin{array}{l}\text { identifikasi temuan ke dalam isu kritis } \\
\text { perspektif keuangan. }\end{array}$}} \\
\hline \multicolumn{2}{|c|}{$\begin{array}{l}\text { BSc. Pada Tabel } 10 \text { adalah contoh } \\
\text { teknisnya. }\end{array}$} & & & & & & & & & \\
\hline \multicolumn{2}{|c|}{$\begin{array}{l}\text { Hasil temuan lingkungan organisasi } \\
\text { tersebut, kemudian dibuat rincian untuk } \\
\text { masing-masing perspektif untuk kemudian }\end{array}$} & & & & & & & & & $\begin{array}{l}\text { adalah } \\
\text { rsebut ke } \\
\text { isu kritis. }\end{array}$ \\
\hline
\end{tabular}


Kinerja Layanan Universitas Islam Indonesia Diukur dengan..., Joko Susilo

Tabel 13

\section{Rumusan Tujuan Strategis dan Tujuan Spesifik Segi Keuangan Direktorat Akademik-Divisi Administrasi Akademik}

\begin{tabular}{|c|c|c|}
\hline \multicolumn{3}{|c|}{ RUMUSAN TUJUAN STRATEGIS DAN TUJUAN SPESIFIK } \\
\hline DIREKTORAT & DIVISI & LAKIP \\
\hline DIREKTORAT AKADEMIK & ADMINISTRASI AKADEMIK & 2005 \\
\hline \multicolumn{3}{|c|}{ ISI KRITIS SEGI KEUANGAN } \\
\hline \multicolumn{3}{|c|}{ 1. Keberlanjutan proses pendidikan } \\
\hline \multicolumn{3}{|c|}{ 2. Jaminan kesejahteraan } \\
\hline \multicolumn{3}{|l|}{ TUJUAN STRATEGIS } \\
\hline \multicolumn{3}{|c|}{ 1. Mempertahankan keberlangsungan proses belajar mengajar di lingkungan UII } \\
\hline \multicolumn{3}{|c|}{$\begin{array}{l}\text { 1. Memperbaiki kualitas kesejahteraan dosen dan karyawan secara umum dengan target } \\
\text { kenaikan } 5 \% \text { per tahun }\end{array}$} \\
\hline \multicolumn{3}{|c|}{ TUJUAN SPESIFIK } \\
\hline \multicolumn{3}{|c|}{ 1. Meningkatkan jumlah pendaftar dengan meningkatkan kualitas layanan adm akademik } \\
\hline \multicolumn{3}{|c|}{ 2. Akuntabilitas keuangan ke pihak stakeholders } \\
\hline \multicolumn{3}{|c|}{ 3. Menggali sumber pendanaan dari luar selain penerimaan dari mahasiswa } \\
\hline \multicolumn{3}{|c|}{ 4. Mengurani jumlah permohonan dispensasi SPP oleh mahasiswa } \\
\hline
\end{tabular}

sasaran, semacam itu perlu dirinci dan dan diberi bobot, yang kemudian digunakan untuk menentukan \%.

Pada Tabel 14 ini contoh teknis kartu BSc yang dibuat untuk Divisi Administrasi Akademik UII.

\section{Menganalisis hubungan antar kartu yang membentuk kartu BSC untuk PTS}

Masing-masing kartu pada setiap unit strategis merupakan sistem kinerja organisasi yang mencakup keempat perspektif BSC. Masing-masing unit atau bagian memiliki perspektif yang bisa jadi berbeda satu dengan yang lain tergantung dari aktivitas yang ada dalam unit tersebut. Ideal penyusunan BSc adalah dimulai dari tinjauan organisasi secara menyeluruh, kemudian dijabarkan dengan BSC untuk direktorat, diikuti penjabaran BSC untuk divisi/unit dan diakhiri dengan penjabaran BSC untuk masing-masing individu dalam unit tersebut sehingga dari sini, pengukuran kinerja BSC untuk organisasi UII adalah mencakup seluruh kinerja BSc mulai dari individu, divisi dan direktorat serta UII secara menyeluruh. Dengan demikian dari sini dapat disimpulkan, bahwa tidaklah mungkin penyusunan BSC ini dilakukan secara terpisah satu dengan yang lain. Masingmasing bagian saling terkait satu dengan yang lain. Bisa saja penyusunan BSC dimulai dari individu ke organisasi (bottom up) hanya saja kesulitan yang ada akan lebih besar dibanding jika penyusunan BSC tersebut dimulai dari tingkat organisasi (top down).

\section{Kesimpulan dan Saran}

Kinerja PTS dalam hal ini adalah Universitas Islam Indonesia, dilihat dengan pendekatan Balanced Scorecard secara umum sudah relatif baik. Hal ini dibuktikan dengan hasil uji statistik dan telaah literatur berupa laporan keuangan untuk perspektif 
UNISIA, Vol. XXX No. 64 Juni 2007

Tabel 14

Kartu BSc-Kartu Kinerja Berimbang

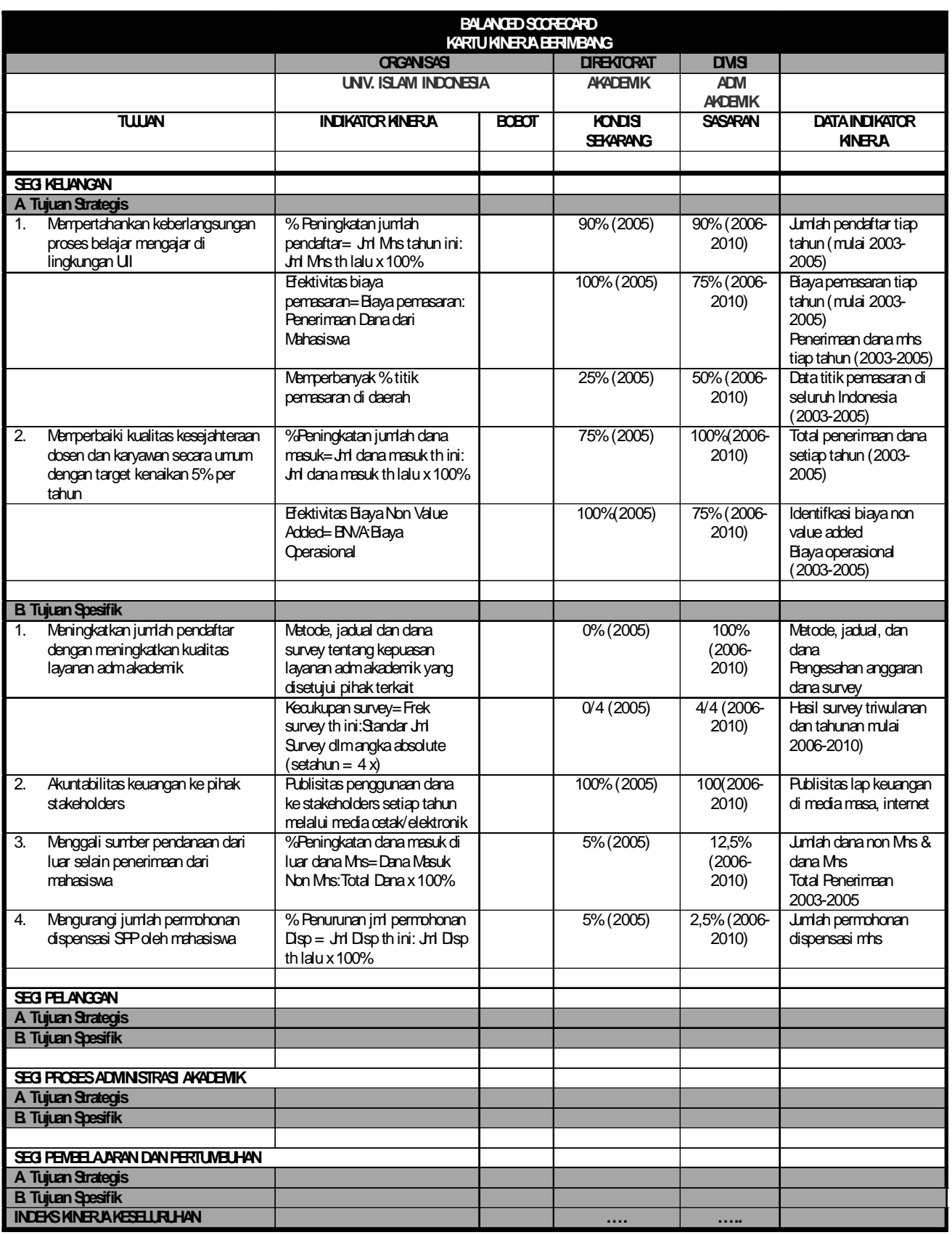

172 
Kinerja Layanan Universitas Islam Indonesia Diukur dengan..., Joko Susilo

keuangan yang menggambarkan bahwa dalam semua aspek atau perspektif BSC, UII dapat dikatakan relatif baik, di tengahtengah krisis pendidikan yang melanda DIY.

Dari hasil uji korelasi H1 menunjukkan bahwa terdapat hubungan antara proses pendidikan dan administrasi sebagai cerminan proses bisnis intern dengan kepuasan mahasiswa. Hasil uji korelasi $\mathrm{H} 2$ membuktikan bahwa tidak ada hubungan yang signifikan antara variabel kepuasan mahasiswa dengan perspektif pembelajaran dan pertumbuhan. Hasil uji korelasi Pearson untuk H3 menunjukkan bahwa, angka korelasi antara variabel pertumbuhan dan pembelajaran dengan proses administrasi akademik (bisnis internal) tidak signifikan. Artinya, tidak ada hubungan yang kuat antara variabel pertumbuhan dan pembelajaran dengan variabel proses bisnis intern, sehingga dari hasi uji ini, H3 juga tidak dapat diterima.

Rancangan model BSC yang dapat diterapkan di PTS, khususnya UII pada prinsipnya harus dikembalikan ke karakter yang bersangkutan. Hal ini mendasar, karena penyusunan BSC haruslah didasarkan pada visi dan misi UII tersebut. Dalam menyusun BSC, idealnya dimulai dari tingkat korporat (universitas) kemudian dijabarkan dalam tingkatan unit bisnis (fakultas), dijabarkan lagi ke dalam tingkatan departemen (program studi), baru kemudian dijabarkan dalam individu/tim. Masing-masing BSC di tiap tingkatan harus terintegrasi satu dengan yang lainnya, sehingga masing-masing BSC saling berhubungan mulai dari penetapan tujuan strategis dan tujuan spesifik, ukuran kinerjanya, bobot dan sasaran yang ingin dicapai, dan indikator kinerja yang dapat diukur, sehingga dari integrasi masingmasing BSC, pengukuran kinerja BSC di tingkat korporat (universitas) merupakan integrasi dari unit-unit di bawahnya.

\section{Daftar Pustaka}

Averson, P. 1998. "What is Balanced Scorecard". Http: // www. balancedscorecard.org./basics/ bsc1.html.

Boland, T dan Alan F. 2000. "A Systems Perspective Of Performance Management In Public Sector Organisations". MCB The International Journal of Public Sector Management, Vol 13 Issue 5 Date ISSN 0951-3558.

Chang, O. H. dan Chow, C. W.1999. "The Balanced Scorecard: A Potential Tool for Supporting Change and Continuous Improvement in Accouting Education". Issues in Accounting Education. Vol. 14, No. 3, August, p. 385412.

Fischer, R.J.1994, "An overview of performance measurement", Public Management, Performance Measurement Special Section, September, pp. 17.

Gaspersz, V.2005. "Sistem Manaje-men Kinerja Terintegrasi Balanced Scorecard dengan Six Sigma untuk Organisasi Bisnis dan Pemerintah". PT Gramedia. Jakarta..

Jowett, P dan Rothwell M. 1988. "Performance Indicator in Public Sector". Macmillan Press. London.

Kaplan, Robert S.1992. "The Balanced Scorecard: Measures that Drive Performance". Havard Business Review (HBR). Januari-Februari. 
UNISIA, Vol. XXX No. 64 Juni 2007

Kaplan, Robert S.1993. "Putting the Balance Scorecard to Work". HBR. September-Oktober.

Kaplan, Robert S dan David P Norton. 1996. "Using the Balanced Scorecard as Strategy Management System. HBR. January-Febuary.

Laporan Pertanggungjawaban Rektor UII Periode 2001-2006. 2006. Yogyakarta.

Meyer, W.M. dan Gupta, V.1994. "The Performance Paradox", Research in Organisational Behavior, Vol. 16, pp. 309-69.

Mulyadi. 2002. "Balanced Scorecard". Jakarta:Salemba Empat.

Mulyadi. 2005. "Sistem Manajemen Strategik Berbasis Balanced Scorecard". Cetakan Pertama, Juni. Yogyakarta:UPP AMP YKPN.

Peursem, K. A. V. 1998. A Theory Of Public Health Sector Report: Forging $A$ New Path. Journal Of Accounting And Public Policy 19 (1).

Price, J.L. 1999. "Handbook of Organizational Measurement". International Journal of Manpower, Vol. 18 No. 4/ 5/6, hal. 305-558. @ MCB University Press, 0143-7720.

Pujiningsih, S. 2004. "Pengukuran Kinerja Perguruan Tinggi Berdasarkan

Pendekatan Balanced Scorecard". Thesis UGM. Jogja.

Ruben, B. D.1999. "Toward A Balanced Scorecard for Higher Education: Rethingking the College and University Excellence Indicators Framework". Higher Education Forum. QCI, Center for Organizational Development and Leadership, Rutgen University 99-02. Fall.

Shaikh, J.M. 2004. Measuring and Reporitng of Intellectual Capital Performance Analysis. "Journal of American Academy of Business". Maret.

Sulistiyowati, F. 2002. Pengukuran Kinerja Institusi Pendidikan Tinggi dengan Pendekatan Balanced Scorecard. "Jurnal Akuntansi dan Keuangan Sektor Publik". Vol. 03, No. 1, Februari.

Tim Studi Pengembangan Sistem Akuntabilitas Kinerja Instansi Pemerintah. 2000. "Pengukuran Kinerja Suatu Tinjauan pada Instansi Pemerintah". BPKP. Jakarta.

Thomas, J. C. 1995. "Performance Measurement-Lesson Learned for Development Management". Fergamon.

Ulupui, I G. K. A. 2002. Petunjuk Menuju Penilaian Kinerja pada Sektor Publik. "Jurnal Akuntansi dan Keuangan Sektor Publik". Vol 03, No. 01, Februari. Hal 10 s/d 16. 